\title{
PENGARUH PERILAKU PERSONAL HYGIENE PETUGAS INSTALASI GIZI TERHADAP ANGKA KUMAN TANGAN
}

\author{
Effect of Personal Hygiene Behaviour towards Hand's Bacteria number of \\ Nutritional Installation Staffs
}

\author{
Inayati $^{1)}$ dan Prasetya Aji Dewanta ${ }^{1)}$ \\ ${ }^{1)}$ Fakultas Kedokteran dan Ilmu Kesehatan Universitas Muhammadiyah Yogyakarta \\ inayati@umy.ac.id
}

\begin{abstract}
Hospital Nutritional Installation supported patients convalescence process. The cleanliness safety and healthy food needs staff personal hygiene. In 2002, 5 to 6 cases of nosocomial infection for every 100 visits to the hospital were caused by food poisoning therefore bad

personal hygiene behavior of nutritional installation staff. The Aim to know the effect of personal hygiene behavior towards hand's bacteria number of nutritional installation staff. The analytical observational method with cross-sectional design on 13 Nutritional Installation staff of RS PKU Muhammadiyah Gamping. Data collection by checklist and a laboratory examination to measure bacteria number. Data analysis by chi-square test to identify the effects between variables. Personal hygiene behavior of the nutritional installation staff is $53.85 \%$ as moderate category and $46.15 \%$ as a good category. Bacteria numbers are $61.54 \%$ have more than the allowed standard and $38.46 \%$ are less than the standard allowed. The highest bacteria number is $3000 \mathrm{CFU} / \mathrm{cm} 2$ and the lowest is $50 \mathrm{CFU} / \mathrm{cm} 2$. Personal hygiene behavior does not affect the bacteria number $(p>0.05)$. There is no significant association statistically between personal hygiene behavior with hand's bacteria number of nutritional installation staff.
\end{abstract}

Keywords: personal hygiene, bacteria number, nutritional installation, nosocomial infection

\begin{abstract}
ABSTRAK
Pelayanan gizi di Rumah sakit merupakan pelayanan penunjang untuk proses penyembuhan pasien. Personal hygiene atau kebersihan pengelola makanan merupakan prosedur menjaga kebersihan makanan yang sehat dan aman. Tahun 2002 terdapat 5 - 6 kasus infeksi nosokomial setiap 100 kunjungan rumah sakit, salah satu penyebabnya keracunan makanan akibat perilaku personal hygiene petugas instalasi gizi yang buruk. Penelitian bertujuan mengetahui pengaruh perilaku personal hygiene terhadap angka kuman petugas instalasi gizi. Metode penelitian observasional analitik dengan desain cross sectional pada 13 petugas Instalasi Gizi di RS PKU Muhammadiyah Gamping. Pengumpulan data menggunakan check list dan uji laboratorium mengukur jumlah angka kuman. Analisis data uji Chi-square untuk mengetahui pengaruh antar variabel perilaku personal hygiene dan angka kuman tangan. Tingkat perilaku personal hygiene petugas instalasi gizi 53,85\% berkategori sedang dan 46,15\% berkategori baik. Angka kuman tangan petugas instalasi gizi 61,54\% melebihi standar angka kuman yang diperbolehkan dan 38,46\% kurang dari standar. Angka kuman yang tertinggi $3000 \mathrm{CFU} / \mathrm{cm} 2$ dan yang terendah $50 \mathrm{CFU} / \mathrm{cm} 2$. Perilaku personal hygiene tidak mempengaruhi angka kuman tangan $(\mathrm{p}>0,05)$. Kesimpulan tidak terdapat pengaruh perilaku personal hygiene terhadap angka kuman tangan petugas instalasi gizi di RS PKU Muhammadiyah Gamping yang signifikan.
\end{abstract}

Kata Kunci : personal hygiene, angka kuman tangan, instalasi gizi 


\section{Pendahuluan}

Menurut Kementerian Kesehatan RI (2013), pelayanan gizi di rumah sakit merupakan pelayanan penunjang untuk proses penyembuhan pasien. Pelayanan gizi juga dilakukan dalam upaya mempercepat proses penyembuhan, serta mempertahankan dan meningkatkan status gizi. Tugas dari petugas instalasi gizi adalah untuk distribusi, pengolahan makanan, serta menjaga mutu dan keamanan makanan pasien. Melihat kepentingan dari fungsi pelayanan gizi, maka makanan sangat perlu diperhatikan keamanannya. Menjaga keamanan makanan salah satunya dengan memperhatikan personal hygiene petugas gizi. Hasil penelitian Cahyaningsih et al. (2009) menunjukkan terdapat hubungan yang bermakna antara tindakan mencuci tangan memakai sabun sebelum bekerja dan setelah dari toilet dengan angka kuman total.

Mikroorganisme pada makanan dapat menyebabkan foodborne disease yaitu gejala penyakit yang timbul akibat mengkonsumsi makanan yang mengandung senyawa beracun dan juga mikroorganisme patogen. (Kemenkes RI, 2013). Data tentang terjadinya infeksi nosokomial khususnya yang berhubungan dengan penyelenggaraan makanan di rumah sakit belum tercatat, akan tetapi timbulnya infeksi nosokomial secara umum diketahui angkanya tergolong tinggi. Centers of Disease Control and Prevention's (CDC's) pada tahun 2002 melaporkan bahwa 5 - 6 kasus infeksi nosokomial dari setiap 100 kunjungan ke rumah sakit. Dua juta kasus infeksi nosokomial terjadi setiap tahun di Amerika Serikat, sedangkan angka infeksi nosokomial di Jakarta sebesar 41,1\%, di Surabaya 73,3\%, dan di Yogyakarta kurang lebih 5,9\% (Hasyim, 2005). Pada penelitian Marwoto et al., (2007) angka infeksi nosokomial di RSUP Sadjito menunjukkan angka $7,85 \%$.

Penelitian pada petugas instalasi gizi penting karena petugas instalasi gizi adalah salah satu staf di rumah sakit yang bertugas untuk menunjang status gizi pasien yang berperan pada proses penyembuhan pasien. Petugas instalasi gizi harus mempraktekkan perilaku personal hygiene yang baik agar dapat mengurangi dampak buruk kontaminasi makanan pasien. Hingga saat ini belum banyak penelitian yang mengevaluasi perilaku personal hygiene petugas 
instalasi gizi. Kebersihan petugas (personal hygiene) gizi sangat perlu

diperhatikan karena selaku pengelola makanan merupakan sumber utama kontaminasi pada makanan. Penelitian bertujuan mengetahui pengaruh perilaku personal hygiene pada petugas instalasi gizi terhadap jumlah angka kuman di tangan.

\section{Metode}

Penelitian kuantitatif dengan metode observasional analitik dengan pendekatan cross sectional untuk mengetahui pengaruh perilaku personal hygiene terhadap angka kuman tangan 13 petugas instalasi gizi di RS PKU Muhammadiyah Gamping. Pengambilan data dengan cara observasi perilaku personal hygiene dan pengambilan swab tangan untuk pemeriksaan angka kuman di Laboratorim Mikrobiologi FKIK UMY dengan metode streak plate. Menurut Emanuel Goldman (2009), penghitungan jumlah angka kuman menggunakan rumus berikut :
Angka Kuman $=\mathrm{n} \times 500 \mathrm{CFU} / \mathrm{ml} / \mathrm{cm}^{2}$ $\mathrm{n}=$ jumlah koloni yang dihitung.

$\mathrm{CFU} / \mathrm{ml} / \mathrm{cm}^{2}$ : Colony Forming Unit $/ \mathrm{ml} / \mathrm{cm}^{2}$ )

\section{Hasil}

Penelitian ini menggunakan total sampling, seluruh petugas Instalasi Gizi yang bekerja di RS PKU Muhammadiyah Gamping, yang memenuhi kriteria inklusi menjadi subjek penelitian. Sebanyak 13 orang yang memenuhi kriteria inklusi terdiri dari 10 orang pegawai tetap dan 3 orang pegawai magang di Instalasi Gizi. Data tersebut didapatkan dari observasi saat bekerja dan mengisi checklist. Subjek paling banyak berjenis kelamin perempuan $(92,31 \%)$ (Tabel 1), tingkat pendidikan SMA/SMK (100\%) (Tabel 2), dengan lama bekerja kurang dari lima tahun $(53,80 \%)$ (Tabel 3).

Tabel 1. Karakteristik petugas Instalasi Gizi RS PKU Muhammadiyah Gamping berdasarkan jenis kelamin

\begin{tabular}{cccc}
\hline No. & Jenis Kelamin & Frekuensi & Persentase \\
\hline 1 & Laki-laki & 1 & $7,69 \%$ \\
2 & Perempuan & 12 & $92,31 \%$ \\
& Total & $\mathbf{1 3}$ & $\mathbf{1 0 0 \%}$ \\
\hline
\end{tabular}


Tabel 2. Karakteristik petugas Instalasi Gizi RS PKU Muhammadiyah Gamping berdasarkan tingkat pendidikan.

\begin{tabular}{cccc}
\hline No. & Tingkat Pendidikan & Frekuensi & Persentase \\
\hline 1 & SMA/SMK & 13 & $100 \%$ \\
2 & D1-D3 & 0 & $0 \%$ \\
3 & D4/S1 & 0 & $0 \%$ \\
& Total & $\mathbf{1 3}$ & $\mathbf{1 0 0 \%}$ \\
\hline
\end{tabular}

Tabel 3. Karakteristik petugas Instalasi Gizi RS PKU Muhammadiyah Gamping berdasarkan

\begin{tabular}{cccc}
\multicolumn{4}{c}{ lamanya bekerja. } \\
\hline No. & Lama Bekerja & Frekuensi & Persentase \\
\hline 1 & $>5$ tahun & 6 & $46,20 \%$ \\
2 & $<5$ tahun & 7 & $53,80 \%$ \\
& Total & 13 & $100 \%$ \\
\hline
\end{tabular}

Hasil observasi perilaku personal hygiene petugas instalasi gizi RS PKU Muhammadiyah Gamping menunjukkan $53,85 \%$ berperilaku sedang dan $46,15 \%$ berperilaku baik (Tabel 4). Berdasarkan checklist menunjukkan bahwa Petugas instalasi gizi $100 \%$ tidak memakai cincin saat melakukan penyajian makanan, memakai penutup kepala, dan tidak menggunakan gadget terutama handphone saat menyajikan makanan. Didapatkan hasil $0 \%$ pada penggunaan sendok saat mencicipi makanan, karena petugas instalasi gizi RS PKU Muhammadiyah Gamping tidak ada kegiatan mencicipi makanan (Tabel 5).

Tabel 4. Hasil observasi perilaku personal hygiene petugas instalasi gizi RS PKU Muhammadiyah Gamping

\begin{tabular}{ccccc}
\hline No. & Interval Skor & Kategori & Frekuensi & Persentase \\
\hline 1 & $\leq 60 \%$ & Buruk & 0 & $0 \%$ \\
2 & $61 \%-79 \%$ & Sedang & 7 & $53,85 \%$ \\
3 & $\geq 80 \%$ & Baik & 6 & $46,15 \%$ \\
& Total & & 13 & $100 \%$ \\
\hline
\end{tabular}

Pada Tabel 6, petugas Instalasi Gizi RS PKU Muhammadiyah Gamping sebanyak 61,54\% memiliki angka kuman tangan yang lebih dari standar angka kuman yang diperbolehkan (487 cfu/ml) dan sebanyak 38,46\% memiliki angka kuman tangan yang kurang dari standar angka kuman yang diperbolehkan (Number of Microorganism on Your Hand, 2008. Diakses pada 3 Mei 2017, dari http://www.handhygiene.net/microorgani $\underline{\text { sms-on-hands) }}$ 
Tabel 7 memaparkan hasil uji chi-square

kuman.

dan Spearman Correlation personal

Tabel 5. Hasil Observasi perilaku personal hygiene yang dilakukan petugas Instalasi Gizi RS PKU Muhammadiyah Gamping berdasarkan checklist.

\begin{tabular}{lc}
\hline \multicolumn{1}{c}{ Perilaku Personal Hygiene yang Dinilai } & Persentase \\
\hline Kuku dalam keadaan pendek dan bersih (tanpa cat kuku) & $95 \%$ \\
\hline $\begin{array}{l}\text { Mencuci tangan standar WHO dengan sabun sebelum memulai kegiatan persiapan penyajian } \\
\text { makanan. }\end{array}$ & $38 \%$ \\
\hline Tidak memakai cincin pada saat melakukan persiapan penyajian makanan. & $100 \%$ \\
\hline Memakai pakaian kerja (apron) yang bersih pada saat kegiatan persiapan penyajian makanan. & $97 \%$ \\
\hline Tidak berbicara pada saat menangani makanan. & $87 \%$ \\
\hline $\begin{array}{l}\text { Pada saat persiapan penyajian makanan, (pria) berambut pendek, tidak berkumis dan } \\
\text { berjanggut, serta (wanita) berambut pendek atau tidak tergerai bila panjang (jika menggunakan } \\
\text { jilbab, jilbab terikat/tidak tergerai) }\end{array}$ & $92 \%$ \\
\hline Memakai alat/sarung plastik sekali pakai pada saat persiapan penyajian makanan. & $64 \%$ \\
\hline Memakai penutup rambut pada saat persiapan penyajian makanan. & $100 \%$ \\
\hline Memakai sendok pada saat penjamah mencicipi makanan & $0 \%$ \\
\hline \begin{tabular}{l} 
Tidak menggunakan gadget saat persiapan penyajian makanan. \\
\hline
\end{tabular}
\end{tabular}

Tabel 6. Hasil angka kuman petugas instalasi gizi di RS PKU Muhammadiyah Gamping

\begin{tabular}{clcc}
\hline No & \multicolumn{1}{c}{ Angka Kuman ( CFU/cm } & Frekuensi & Persentase \\
\hline 1 & Lebih dari standar Angka Kuman yang diperbolehkan & 8 & 61,54 \\
2 & Kurang dari standar Angka Kuman yang diperbolehkan & 5 & 38,46 \\
\hline
\end{tabular}

Tabel 7. Hasil uji statistik chi-square dan Spearman Correlation

\begin{tabular}{|c|c|c|c|}
\hline Variabel & \multicolumn{2}{|c|}{ Angka Kuman } & \multirow[b]{2}{*}{ Total } \\
\hline Personal Hygiene & $\begin{array}{l}\text { Kurang dari standar Angka } \\
\text { Kuman yang diperbolehkan }\end{array}$ & $\begin{array}{l}\text { Lebih dari standar Angka } \\
\text { Kuman yang diperbolehkan }\end{array}$ & \\
\hline Baik & $\begin{array}{c}3 \\
23,10 \%\end{array}$ & $\begin{array}{c}3 \\
23,10 \%\end{array}$ & $\begin{array}{c}6 \\
46,20 \%\end{array}$ \\
\hline Sedang & $\begin{array}{c}2 \\
15,40 \%\end{array}$ & $\begin{array}{l}5 \\
38,50 \% \\
\end{array}$ & $\begin{array}{c}7 \\
53,80 \% \\
\end{array}$ \\
\hline Buruk & $\begin{array}{c}0 \\
0 \%\end{array}$ & $\begin{array}{c}0 \\
0 \%\end{array}$ & $\begin{array}{c}0 \\
0 \%\end{array}$ \\
\hline Total & $\begin{array}{c}5 \\
38,50 \% \\
\end{array}$ & $\begin{array}{c}8 \\
61,50 \% \\
\end{array}$ & $\begin{array}{c}13 \\
100 \%\end{array}$ \\
\hline & $\begin{array}{l}\text { er's Exact Test } \\
\text { Odds Ratio }\end{array}$ & $\begin{array}{c}p=0,592 \alpha=0,0 \\
O R=2,500 \\
p=0,443\end{array}$ & \\
\hline
\end{tabular}


Dari analisis didapatkan nilai Fisher's Exact Test dengan $\mathrm{p}=0,592$, artinya tidak terdapat pengaruh perilaku personal

hygiene terhadap angka kuman tangan petugas Instalasi Gizi RS PKU Muhammadiyah Gamping. Dalam penelitian ini didapatkan nilai OR sebesar 2,5, maka resiko terjadinya angka kuman tangan yang lebih dari standar angka kuman yang diperbolehkan pada petugas instalasi gizi RS PKU Muhammadiyah Gamping, yang memiliki perilaku personal hygiene yang sedang 2,5 kali lebih besar dibanding petugas instalasi gizi yang memiliki perilaku personal hygiene yang tinggi, namun demikian , odds ratio pada hasil uji statistik ini tidak bermakna karena didapatkan nilai $\mathrm{p}=$ $0,443(>0,05)$, sehingga hasil tidak mewakili seluruh populasi.

\section{Pembahasan}

Jenis kelamin petugas instalasi gizi terdiri dari 1 orang laki-laki $(7,69 \%)$ dan 12 orang perempuan $(92,31 \%)$. Petugas Instalasi Gizi RS PKU Muhammadiyah Gamping didominasi oleh perempuan, sehingga kemungkinan pekerjaan lebih baik dikarenakan perempuan lebih rajin dan teliti dalam bekerja, sebaliknya perilaku seorang laki- laki ada kecenderungan menganggap remeh suatu pekerjaan dibanding perempuan (Samani, 2011).

Tingkat pendidikan petugas Instalasi Gizi pada penelitian ini terdapat 13 orang $(100 \%)$ pendidikan terakhirnya adalah SMK Tata Boga. Harapannya, lulusan SMK Tata Boga dapat lebih mengerti tentang pekerjaan yang berhubungan dengan makanan terutama tentang keamanan makanan dan personal hygiene dan mampu menerima informasi terutama cara mengolah makanan. Temuan ini mirip dengan hasil penelitian Cahyaningsih et al., (2009), bahwa pendidikan yang tinggi tidak mempengaruhi kebiasaan perilaku sanitation hygiene. Tingkat pendidikan para penjamah makanan tersebut adalah SMA, namun demikian belum pernah mendapatkan penyuluhan atau pelatihan mengenai hygiene, sehingga perilaku kurang baik tersebut dikarenakan ketidaktahuan para penjamah makanan. Untuk meningkatkan kualitas makanan yang disajikan maka perlu adanya peningkatan pengetahuan melalui pemberian pelatihan/kursus dan praktik lapangan terhadap pengelola, pengolah, penyaji makanan, serta para pembina dan pengawas kebersihan makanan di 
lapangan, seperti yang dikemukakan Djaja (2005).

Karakteristik lamanya bekerja petugas instalasi gizi pada penelitian ini terdapat 6 orang $(46,15 \%)$ telah bekerja lebih dari 5 tahun dan 7 orang $(53,85 \%)$ telah bekerja kurang dari 5 tahun. Petugas instalasi gizi yang telah bekerja lebih dari 5 tahun, harapannya telah memiliki keterampilan dan kecepatan saat bekerja. Hal ini sesuai dengan penelitian Widiastuti (2007) bahwa lamanya bekerja akan mempengaruhi keterampilan dalam melaksanakan tugas. Semakin lama bekerja maka ketrampilan akan semakin meningkat. Pada penelitian ini petugas instalasi gizi yang bekerja lebih dari 5 tahun lebih sedikit dibandingkan yang bekerja kurang dari 5 tahun, sehingga mempengaruhi ketrampilan bekerja termasuk personal hygiene saat bekerja yang ditunjukkan dengan jumlah angka kuman tangan. Petugas instalasi gizi dengan angka kuman tangan lebih dari standar angka yang diperbolehkan lebih sedikit daripada petugas gizi dengan angka kuman yang kurang dari standar angka yang diperbolehkan, hal ini selaras dengan lama waktu bekerja .

Tujuh orang $(53,85 \%)$ petugas instalasi gizi memiliki perilaku personal hygiene dalam kategori sedang dan sebanyak $6(46,15 \%)$ petugas instalasi gizi memiliki perilaku personal hygiene dalam kategori baik, dan tidak ada petugas instalasi gizi yang memiliki perilaku personal hygiene yang buruk. Menurut Weaver et al. (2016) untuk mencegah infeksi nosokomial di rumah sakit, fasilitas pelayanan gizi harus menerapkan program "WASH" yaitu washing, sanitation, hygiene. Hal tersebut memberikan gambaran bahwa fasilitas penunjang untuk melakukan personal hygiene yang baik dan lengkap juga sangat dibutuhkan.

Dalam penelitian ini personal hygiene petugas instalasi gizi sudah relatif baik karena pekerjaan pengelolaan, pengolahan dan penyajian makanan sudah difasilitasi dengan sarana dan prasarana yang memadai dan sesuai standar, sebagaimana yang ditunjukkan pada saat akan melakukan kegiatan persiapan penyajian makanan, sebanyak 97\% petugas instalasi gizi memakai pakaian kerja (apron) yang bersih, 64\% petugas instalasi gizi memakai alat/sarung plastik sekali pakai dan $100 \%$ petugas instalasi gizi memakai penutup rambut. Hal tersebut sangat mempengaruhi personal hygiene petugas instalasi gizi, akan tetapi terdapat satu hal yang kurang yaitu hanya 38\% petugas 
instalasi gizi yang mencuci tangan standar WHO dengan sabun sebelum memulai kegiatan persiapan penyajian makanan.

Meningkatkan perilaku personal hygiene sangat diperlukan adanya pengetahuan tentang personal hygiene yang baik (Rahman, et al., 2012). Sebanyak 5\% petugas gizi masih memiliki kuku yang panjang. Kuku yang panjang memiliki angka kuman sebanyak 61.368 CFU/ $/ \mathrm{cm}^{2}$ sehingga berdampak pada peningkatan kejadian kontaminasi (Number of Microorganism on Your Hands, 2008). Semua petugas instalasi gizi tidak menggunakan cincin saat menyajikan makanan. Sejalan dengan hasil penelitian Acikel et al. (2008) bahwa sebanyak $80 \%$ penjaman makanan yang sudah diberi pelatihan mengenai personal hygiene tidak menggunakan jam tangan dan perhiasan seperti cincin atau gelang. Sikap atau tindakan tersebut yang mendukung penurunan angka kuman tangan pada penjamah makanan yang telah diberi pelatihan tentang personal hygiene. Rumah Sakit sudah melakukan pelatihan tentang personal hygiene bagi petugas instalasi gizi, akan tetapi masih perlu melakukan pelatihan secara periodik dan berkesinambungan untuk meningkatkan pengetahuan dan keterampilan petugas instalasi gizi dalam melakukan kegiatan pengelolaan, pengolahan dan penyajian makanan.

Semua petugas instalasi gizi mencuci tangan dan mengeringkannya, akan tetapi hanya 38\% yang mencuci tangan standar WHO dan dengan menggunakan hand $r u b$ yang mengandung alkohol. Temuannya berseberangan dengan hasil penelitian Shojaei et al. (2006) bahwa simple hand-washing dapat menurunkan kontaminasi kuman di tangan penjaman makanan, sehingga menurunkan kontaminasi kuman pada makanan. Lama waktu yang diperlukan saat mencuci tangan adalah 40-60 detik (WHO, 2009). Mencuci tangan dengan sabun dan air, atau desinfeksi menggunakan alcoholbased hand rub sebagai tolok ukur paling penting untuk mencegah infeksi nosokomial (Erasmus, et al. 2010).

Dalam penelitian ini angka kuman tangan petugas instalasi gizi yang lebih dari angka kuman yang diperbolehkan lebih besar daripada angka kuman tangan petugas instalasi gizi yang kurang dari angka kuman yang diperbolehkan. Hal tersebut menunjukkan angka kuman tangan petugas instalasi gizi dipengaruhi oleh kebiasaan mencuci tangan sesuai WHO yang masih rendah yaitu $38 \%$. Mencuci tangan yang tidak sesuai standar 
WHO memungkinkan kuman yang ada di tangan tidak mati secara sempurna.

Penggunaan alat/sarung tangan khusus sangat diperhatikan saat penyajian makanan. Pada penelitian ini sebanyak $64 \%$ petugas instalasi gizi yang menggunakan sarung tangan plastik. Selain itu, sebanyak $100 \%$ petugas instalasi gizi tidak menggunakan gadget, sebagai bentuk upaya petugas dalam mengurangi kontaminasi pada tangan, karena handphone layar sentuh biasanya telah terkontaminasi bakteri. Hal ini sesuai dengan penelitian Mark et al. (2014) penggunaan handphone layar sentuh menyebabkan kontaminasi bakteri pada tangan tenaga medis. Kontaminasi bakteri pada handphone layar sentuh lebih sedikit daripada handphone dengan key-pad. Oleh sebab itu penggunaan gadget pada saat bekerja harus diimbangi dengan hand hygiene yang bagus.

Diketahui angka kuman tangan petugas Instalasi Gizi RS PKU Muhammadiyah Gamping yang kurang dari standar angka kuman yang diperbolehkan sebanyak $38,46 \%$ dan yang lebih dari standar angka kuman yang diperbolehkan sebanyak $61,54 \%$. Angka kuman tertinggi adalah 3.000 $\mathrm{CFU} / \mathrm{cm}^{2}$ dan yang terendah adalah 50 $\mathrm{CFU} / \mathrm{cm}^{2}$. Berdasarkan penelitian Cairo et al. (2008) bahwa, penelitian yang dilakukan di rumah sakit anak di Brazil menemukan bakteri patogen pada tangan petugas instalasi gizi. Keadaan bakteri patogen dikaitkan dengan perilaku personal hygiene yang buruk. Kontaminasi di tangan ini dapat berdampak pada kontaminasi pada makanan pasien melalui piring/alat makan dan makanan yang dijamah oleh petugas instalasi gizi. Hal ini sesuai dengan penelitian Riga et al. (2015) yang telah menemukan beberapa bakteri patogen pada permukaan piring pasien.

Penelitian ini tidak terdapat pengaruh perilaku personal hygiene terhadap angka kuman tangan petugas instalasi gizi. Dengan demikian petugas instalasi gizi dengan personal hygiene yang baik atau buruk tetap sama dalam mendapatkan kontaminasi kuman di tangan. Jika dibandingkan dengan penelitian Acikel et al. (2009) yang menyatakan ada hubungan yang signifikan antara perilaku personal hygiene pada pre-training dan posttraining dengan kualitas bakteriologis di tangan penjamah makanan.

Dilaporkan bahwa terdapat beberapa faktor yang mempengaruhi, yaitu faktor dari dalam dan dari luar petugas instalasi gizi. Faktor dari dalam 
dapat disebabkan oleh lama kerja, durasi mencuci tangan, aktivitas yang dilakukan, pengetahuan dan pengalaman, perilaku personal hygiene termasuk cara mencuci tangan. Aktivitas yang dilakukan antar petugas instalasi gizi berbeda sesuai tugas masing-masing. Selain mengerjakan tugas pokok, para petugas instalasi gizi juga yang mendistribusikan makanan ke bangsal, mengambil kembali sisa kotoran makanan serta piring ke bangsal, dan juga yang mencuci piring-piring tersebut. Aktivitas tersebut memungkinkan akan terjadi kontaminasi pada tangan personal hygiene. Aktivitas tambahan tersebut harus diimbangi dengan perilaku cuci tangan yang baik untuk menghindari transmisi kuman ke makanan yang disajikan. Terjadi perbedaan angka kuman antar petugas gizi bisa disebabkan oleh sebelum pengambilan sampel apakah petugas instalasi gizi telah mencuci tangan atau belum. Faktor dari luar disebabkan oleh kontaminasi lingkungan instalasi gizi.

Pada penelitian ini perilaku personal hygiene petugas instalasi gizi tidak mempengaruhi angka kuman tangan petugas instalasi gizi secara statistik karena keterbatasan jumlah subyek penelitian, dimana odds ratio didapatkan nilai $\mathrm{p}=0,443(>0,05)$ tidak bermakna sehingga hasil tidak mewakili seluruh populasi, akan tetapi angka kuman tangan yang lebih dari standar angka kuman yang diperbolehkan petugas instalasi gizi dengan personal hygiene yang sedang 2,5 kali lebih besar dibanding petugas instalasi gizi dengan personal hygiene yang tinggi, sehingga personal hygiene yang semakin baik akan mempengaruhi angka kuman tangan petugas instalasi gizi yang lebih rendah dari angka kuman standard yang diperbolehkan.

Penelitian yang serupa dan sejalan dengan penelitian ini dilakukan oleh Supeni (2006) dengan hasil yang tidak signifikan antara perilaku dan teknik cuci tangan perawat dengan angka bakteri penyebab infeksi nosokomial. Demikian pula dengan penelitian Anantajati (2015) tidak terdapat hubungan antara perilaku personal hygiene dengan keberadaan kuman pada tangan petugas katering. Hal ini juga disebabkan oleh aktivitas yang dilakukan dan kontaminasi dari lingkungan.

Kualitas bakteriologis pada tangan petugas medis/paramedis yang buruk menyebabkan terjadinya infeksi nosokomial pada pasien yang dirawat. Menurut Acikel et al. (2009) salah satu tindakan pencegahan transmisi bakteri tersebut melalui pelatihan yang dilakukan 
secara periodik. Ada atau tidaknya bakteri pada tangan petugas medis/paramedis menunjukkan perilaku personal hygiene dan pengetahuan tentang infeksi nosokomial.

\section{Kesimpulan}

Tingkat perilaku personal hygiene petugas Instalasi Gizi RS PKU Muhammadiyah Gamping memiliki kategori sedang sebanyak 53,85\% dan kategori baik 46,15\%. Tidak terdapat pengaruh yang signifikan secara statistik antara perilaku personal hygiene terhadap angka kuman tangan petugas Instalasi Gizi RS PKU Muhammadiyah Gamping.

\section{Daftar Pustaka}

Acikel, C. H., Ogur, R., Yaren, H., Gocgeldi, E., Ucar, M., Kir, T., (2008). The Hygiene Training of Food Handlers at a Teaching Hospital. Food Control ELSEVIER 19 (2008) 186-190

Anantajati, P, (2015). Hubungan Pengetahuan dan Praktik Higiene Perorangan dengan Angka Kuman dan Bakteri Patogen pada Penjamah Makanan di Katering PT. Pim Kalimantan Timur. Yogyakarta: Universitas Gadjah Mada

Cahyaningsih, C.T., Kushadiwijaya, H., Tholib, A., (2009). Hubungan Higiene Sanitasi dan Perilaku Penjamah Makanan dengan Kualitas Bakteriologis Peralatan Makan di
Warung Makan. Berita Kedokteran Masyarakat Vol. 25, No. 4, 180-188.

Cairo, R., Silvia, L., Andrade, C., Santos, K., Antos, D., et al. (2008). Bacterial Contamination in Milk Kitchen in Pediatric Hospital in Salvador, Brazil. Braz J Infect Dis/ 2008;12(3).

Centers of Disease Control and Prevention's. (2002). Healthcareassociated Infections (HAI). Diakses pada 6 Mei 2017, dari https://www.cdc.gov/hai/surveillance I

Emanuel Goldman, Lorrence H. Green, 2009, Practical Handbook of Microbiology, CRC Press, Taylor \& Francis Group

Erasmus, V., Daha, T. J., Brug, H., Richardus, J. H., Behrendt, M., Vos, M., et al., (2010). Systematic Review of Studies on Compliance with Hand Hygiene Guidelines in Hospital Care. Chicago Journal.

Hasyim, H. (2007). Manajemen Hyperkes dan Keselamatan Kerja di Rumah Sakit (Tinjauan Kegiatan Keselamatan dan Kesehatan Kerja di Institusi Sarana Kesehatan). Jurnal JMPK 2007; 08(02).

Kementrian Kesehatan RI. (2013). Pedoman Pelayanan Gizi Rumah Sakit. Jakarta

Mark, D., Leonard, C., Breen, H., Graydon, R., O'Groman, C., Kirk, S., (2014).

Mobile Phone in Practical Practices: Reducing the Risk of Bacterial Contamination. The International Journal of Clinical Practice. 68, 9, 1060-1064 
Number of Microorganism on Your Hand. (2008). Number of Microorganism on Your Hand. Diakses pada 3 Mei 2017, dari http://www.handhygiene.net/microor ganisms-on-hands/

Rahman, M. M., Arif, M. T., Bakar, K., Tambi, Z. B., (2012). Food Safety Knowledge, Attitude and Hygiene Practices Among The Street Food Vendors in Northern Kuching City, Sarawak. Borneo Science. Malaysia: Universiti Malaysia Serawak.

Riga, P. N., Buntuan, V., Rares, F., (2015). Isolasi dan Identifikasi Bakteri Aerob yang Dapat Menyebabkan Infeksi Nosokomial di Ruangan Instalasi Gizi Blu Rsup Prof. Dr. R. D. Kandou Manado. Jurnal e-Biomedik (eBm). Volume 3, Nomor 1, Januari-April 2015

Samani., Haryanto (2011) Faktor-faktor dan Penyebab Perilaku Menyimpang. Bandung: PT Remaja Rosdakarya, 2011.

Shojaei, H., Shooshtaripoor, J., Amiri, M., (2006). Efficacy of Simple Hand-Washing in Reduction of Microbial Hand Contamination of Iranian Food Handlers. Food Research International 39 (5), 525529.

Supeni, M., (2006). Hubungan Perilaku Cuci Tangan Perawat dengan Angka Kuman Bakteri Aerob Penyebab Infeksi Nosokomial. Karya Tulis Ilmiah Strata Satu. Universitas Muhammadiyah Yogyakarta, Yogyakarta.

Weaver, E. R. N., Agius, P. A., Veale, H., Dorning, K., Hlang, T. T., Aung, P. P., et al., (2016). Water,
Sanitation, and Hygiene Facilities and Hygiene Practices Associated with Diarrhea and Vomiting in Monastic Schools, Myanmar. The American Society of Tropical Medicine and Hygiene. 95(2), 2016, pp. 278-287

World Health Organization. (2009). WHO Guidelines on Hand Hygiene in Health Care: First Global Patient Safety Challenge Clean Care Is Safer Care. 